\title{
Keeping the Floating House Afloat in Banjarmasin: Implementation Potential of EPS Floating Technology for Foundation Engineering
}

\author{
Yulianto P. Prihatmaji ${ }^{1,}$, and Dimas $H$. Nugraha ${ }^{2}$ \\ ${ }^{1}$ Department of Architecture, Faculty of Civil Engineering and Planning, Universitas Islam Indonesia \\ ${ }^{2}$ Research and Development Office for Human Settlements Technology Applied, Ministry of Public \\ Works and Housing, Indonesia
}

\begin{abstract}
Banjarmasin, South Kalimantan has traditional house in form of Lanting/ raft house. At present the population of Lanting house is lacking, among others, due to the funding of bamboo house is quite expensive. Ministry of Public Works and Housing R and D Agency was built Floating meeting hall in Semarang 2016 ago with EPS technology. Since the foundation of the bamboo is more expensive and the number of bamboo is fewer, this study eagers to see to what extent the typology analysis of exsisting Lanting house, to see the characteristic of floaing technology (EPS) as a substitude of conventional lating foundation, the engineering of Lanting house design using EPS and how is the comparation of material characteristic of local float and EPS pontoon. Research approach with qualitative and supported by quantitative data. Conclusions are the construction of Lanting house roof generally uses saddle shape, a light and simple roof construction. All Lanting houses in Martapura river uses saddle roof construction. The load capacity EPS per module meter is 5 tons per kg. This Pontoon technology is the result of fabrication that can be applied for various structural and architectural purposes both on land and on water. Having advantages other than environmentally friendly and the dimensions of structural materials can be custom this material has a heat resistance of up to 600. From Comparison of characteristic of local float material and EPS pontoon, EPS pontoon is reliable and better than float material.
\end{abstract}

\section{Introduction: Banjarmasin a Thousand Rivers City}

Banjarmasin city is the capital of South Province located in southern Kalimantan island and directly adjacent to the Java sea. Geographically is located between $3^{\circ} 16^{\prime} 46^{\prime \prime}$ up to $3^{\circ} 22^{\prime} 54^{\prime \prime}$ South Latitude and $114^{\circ} 31^{\prime} 40^{\prime \prime}$ up to $114^{\circ} 39^{\prime}$ '55' East Longitude and has an area $98,46 \mathrm{Km}^{2}$ (BPS, 2017)

\footnotetext{
* Corresponding author: prihatmaji@uii.ac.id
} 
Physically, Banjarmasin city is located in the side of Barito river and split by Martapura river, generally the morfology location of Banjarmasin is relatively dominated flat area and located in low land. The hydrology condition of city is affected by the Barito river and divided into two by Martapura river as main river which both of them dominantly affect their hydrology condition. With a distance of $\pm 23 \mathrm{~km}$ from the sea, hence the river water level is highly affected by sea tide. The traditional house in Banjarmasin in the form of Lanting/raft house and its condition is rare nowadays.

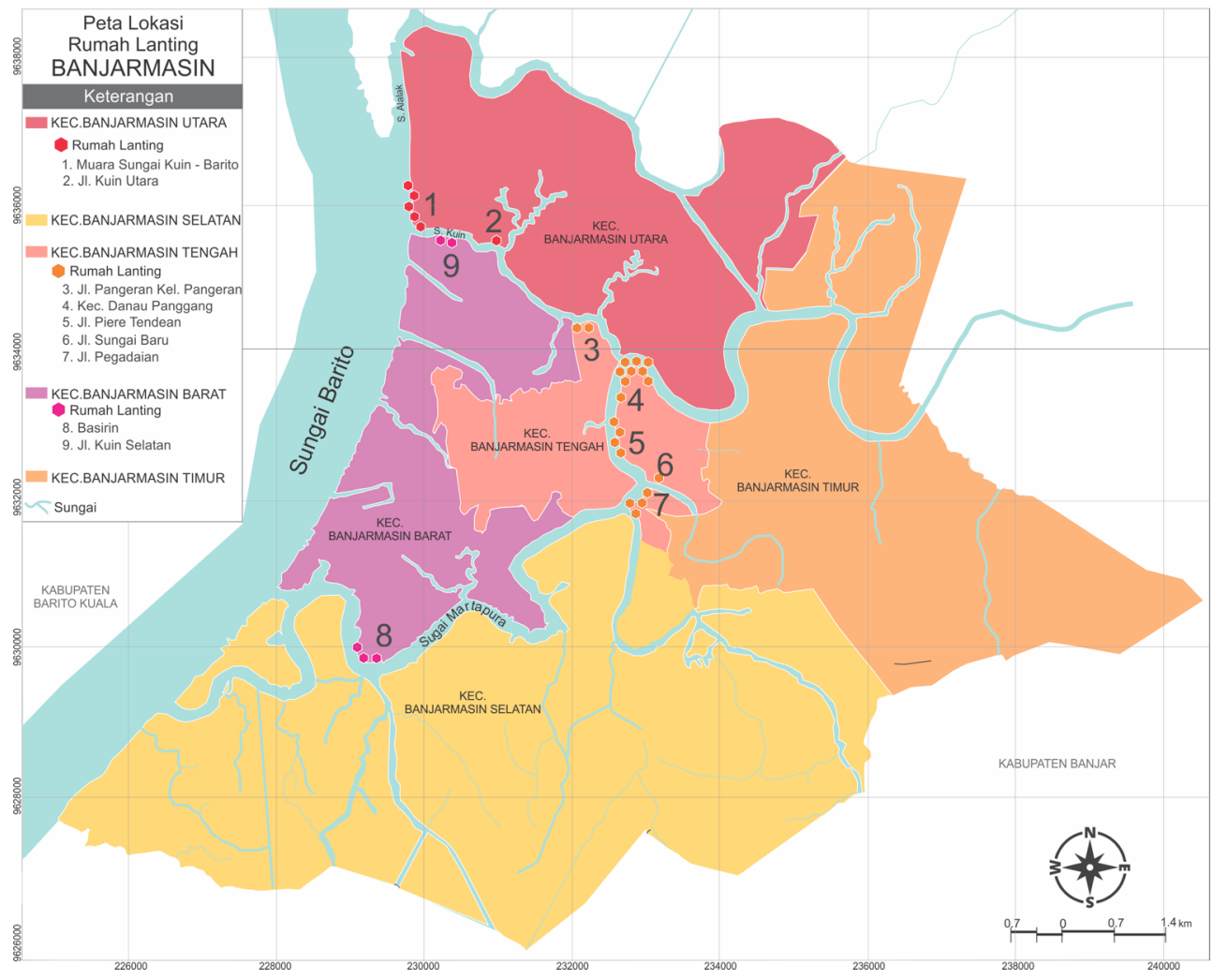

Fig. 1. Distribution of Lanting house in Banjarmasin City

Source: R\&D Center Research Final Report Housing Technology Implementation, PUPR 2017

The Lanting house can be seen in Martapura river and Kuin river based on literature data compilation of Lanting house: House on Top of Water as an Aspect Review of Building Typology and loss proceeding on building and area as effect of the rise of sea water level in Indonesia Beach cities

In the figure 1 indicates the location of Lanting houses in Banjarmasin City, north Banjarmasin sub district, the Lanting houses can be found in estuary of Kuin and Barito river at number 1 and northern Kuin road at number 2. Central Banjarmasin sub district in Pangeran road, Pangran village, Panggang lake sub district, Piere Tendean road, Sungai Baru road, and Pegadaian road. Westhern South Banjarmasin sub district in Basirin and South Kuin road. The foundation of this Lanting house is derived from local bamboo in surrounding of the Lanting house location. At present the population of Lanting house is lacking, among others, due to the funding of bamboo house is quite expensive (Daryanto, 2016) 
Recently, the R\&D of the Ministry of Public Work and Housing applies floating house in Tambaklorok, Tanjung Emas village, North Semarang sub district, Semarang city in 2016. This floating house has wide of $150 \mathrm{~m}^{2}$ and comprising of 2 floors, in which the first floor addressed destined for meeting hall and second floow for children reading room. The foundation of this floating house uses EPS (Extended Polystream Foam).

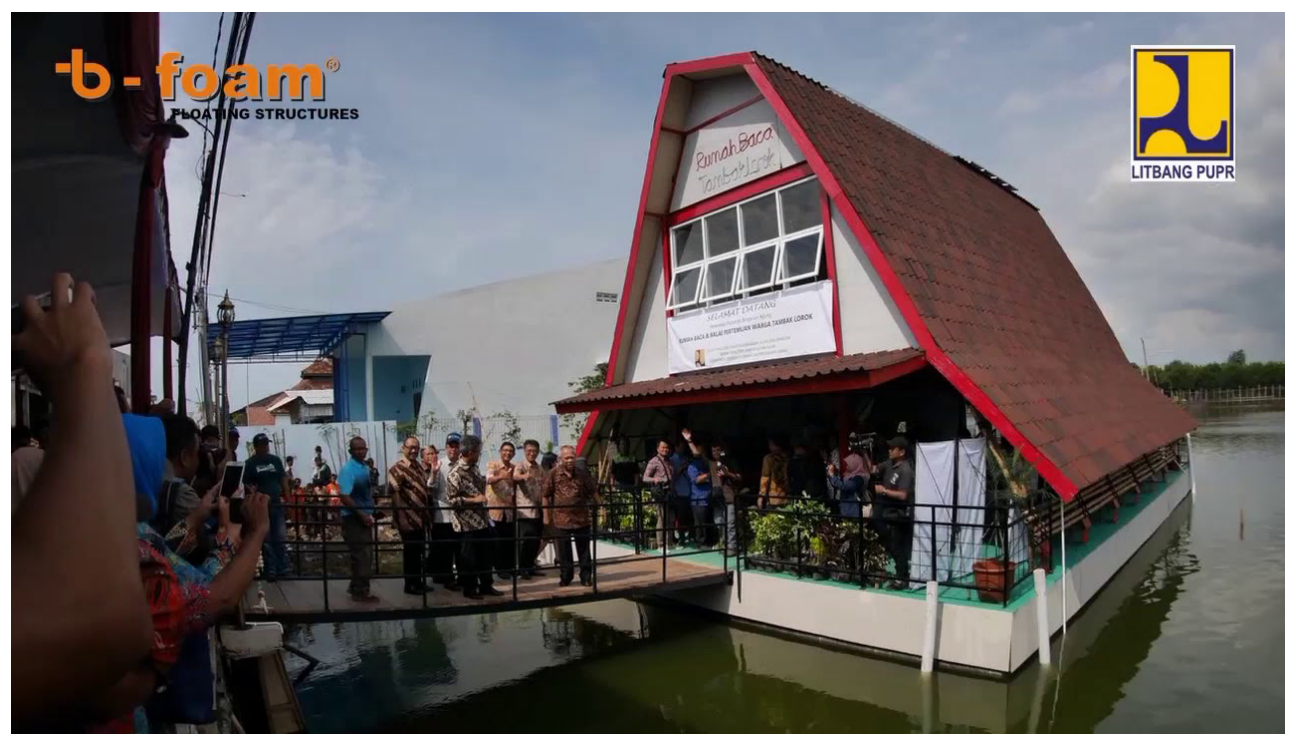

Fig. 2. Floating Meeting Hall in Tambaklorok Semarang Source: B-Foam, 2017

Since the foundation of the bamboo is more expensive and the number of bamboo is fewer, this study eagers to see to what extent: 1) the typology analysis of exsisting Lanting house 2) to see the characteristic of floaing technology (EPS) as a substitude of conventional lating foundation 3) the engineering of Lanting house design using EPS and 4) how is the comparation of material characteristic of local float and EPS pontoon

\section{Method}

This study uses qualitative methods, the result of combinations of primary data from field observation and secondary data. The primary data collection method was conducted by the researchers directly through field observations along the Martapura river, interviews with the residents of the Lanting houses and data documentation. Secondary documents were collected by collecting documents related to Lanting houses. These are previous studies, papers, and regional regulations. For typology, this study also take from previous study.

The scope of this study are 1) Analysis of typology of Lanting house 2) observe the character of EPS as a substitute of Lanting foundation 3) the engineering of Lanting house design with EPS and 4) how is the Comparison of characteristic of local float and EPS pontoon materials. 


\section{Results and Discussions}

\subsection{Building Typology in Martapura riverbank}

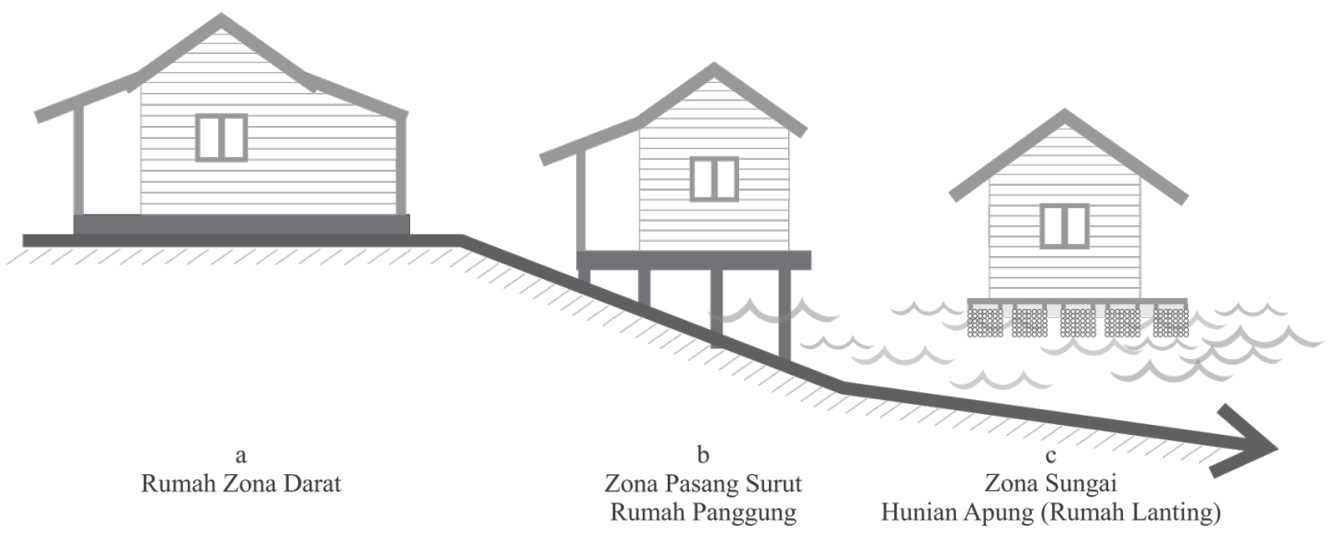

Fig. 3. Habitation of Martapura riverbanks, Banjarmasin

Source: Settlement Technology Applied R\&D Center Report PUPR, 2017

Figure 3 suggests the type of building existing in habitation of Martapura riverbanks in Banjarmasin city. Land zone house (a) has a building construction like other building in general that does not require particular maintenance, the difference is the land right is belong to the head of the family. In (b) and (c) zone the landowner is government. The construction of the building (b) is using construction of stilt foundation of wood material which generally used is ironwood. Cost incurred for stilt house construction is more expensive in the beginning compared to building (c) however the housing with stilt construction does not need specific maintenance annually like ordinary building (c). Martapura river in the beginning of construction has cheaper material with the consequences is maintenance every once in 2 years to replace weathered bamboo, so it does not disturb the balance and stability of the house.

Other differences between building (a), (b) and (c) are land housing dimension (a) and stilt housing (b) have larger dimension and more complex of space function division compared to traditional floating house (a) that has smaller dimension and simpler space function.

\subsection{Typology of Lanting house in Banjarmasin}

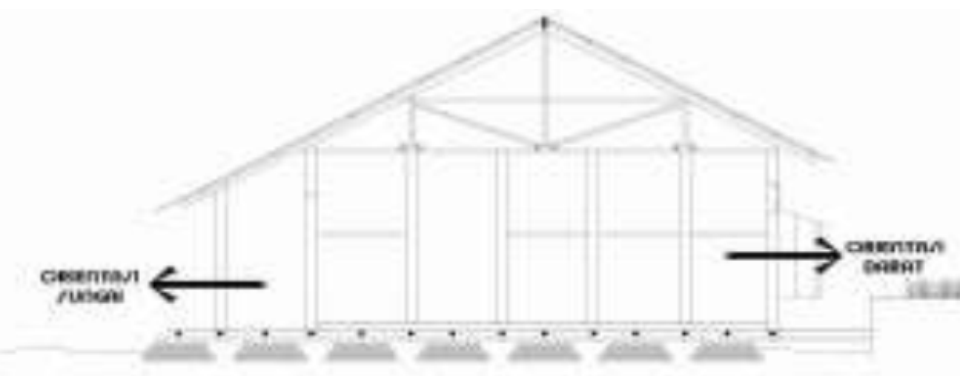

Fig. 1. Cutting of Lanting house

Source: Housing Technology Applied R\&D Center Report PUPR,2017 
Typology of Lanting house in Banjarmasin, the construction of Lanting house roof generally uses the shape of saddle, light and simple roof construction. All Lanting house in Martapura river uses saddle shape roof. Unlike the Lanting house in Panggang Lake sub district there are several Lanting house uses shield roof construction. Material used in the building depends on the economic level of the owner. The percentage of roof shape and material in Martapura river, the shape of all roof is saddle and its building material mostly made of zinc and Sago palm leaves. Other percentage of the building material is in the form of Sago palm leaves and shingle board.
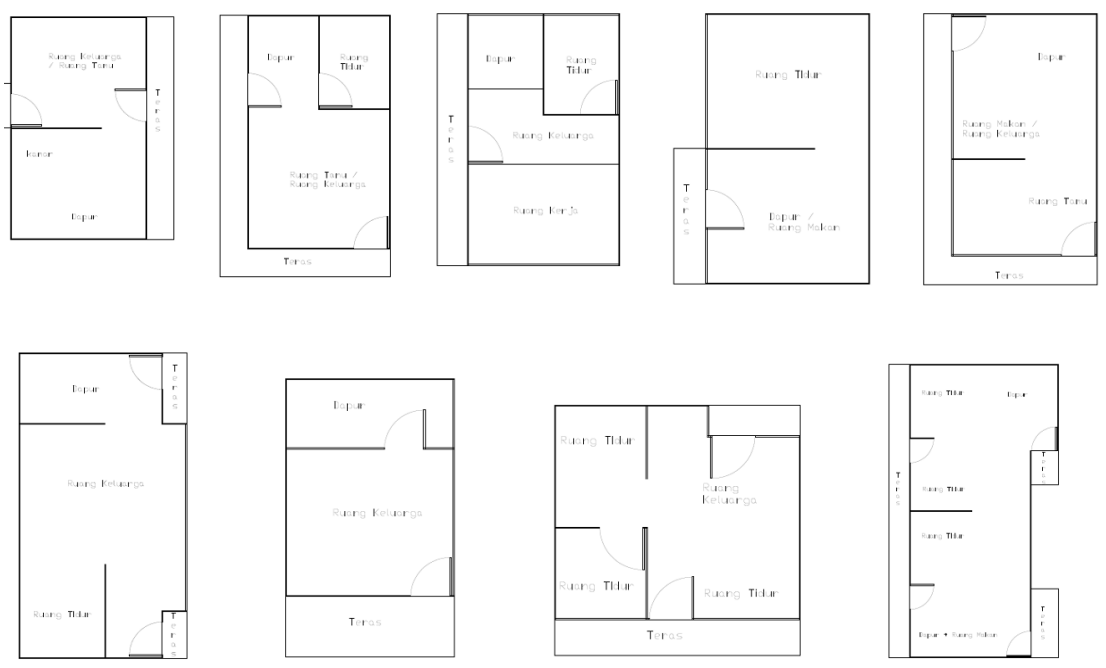

Fig. 5. Element of Lanting house Structure Source: Rahman, 2014

Regarding a walls as the element of Lanting house walls generally uses lanan board arranged horizontally. The maintenance for walls is just by replacing wall material on the part of broken board. The typology of space in figure 5 indicates samples of Lanting house pattern, every sketch and lay out of its space function represent the difference of the owner's needs. In addition to Lanting house pattern as a residential house, there are Lanting house pattern serves as business spot and combination between business and residential. The typology of building structure, all Lanting house in Sungai Baru area uses local bamboo or wooden $\log s^{3}$. 


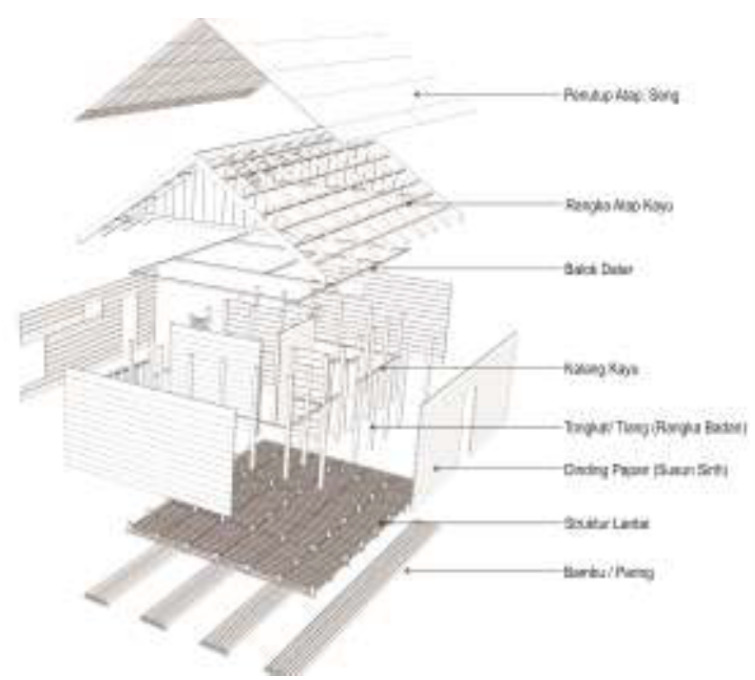

Fig. 6. Element of Lanting house Structure

Source: Rahman, 2014
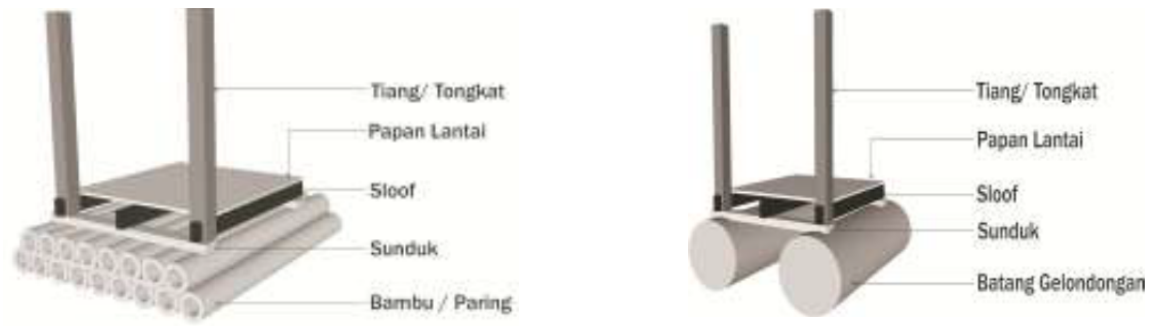

Fig. 7. The Technology of the Structure of Floating Foundation of Lanting house Source: Rahman, 2014

At figure 7 can be seen the structure of Lanting house foundation is a conventional construction using local material. Materials used generally are bamboo, wooden logs, and used iron drums. The structure of the floating is arranged by attaching one another using iron sink before the floor frame is placed above the sloof block or floor. Iron drum material used on building which serves more than a residential function namely for business spot, this building can be located along the Martapura river.

\subsection{Characteristic of EPS Pontoon Foundation Technology}

EPS Pontoon is a modular element structure that uses EPS base material. The main component of Expanded Polystyrene (EPS) Foam is styrena (C8H8), derived from petroleum or natural gas and formed by the reaction between ethylene $(\mathrm{C} 2 \mathrm{H} 4)$ and benzene (C6H6), benzene produced from coal or synthesized from petroleum. Others characteristic from EPS component are density value $15-17 \mathrm{~kg} / \mathrm{m} 3$, thermal conductivity $0,036 \mathrm{~W} / \mathrm{mK}$. Pressure strength $85 \mathrm{kPa}$ and absorption 0,5-1,5\%. Pontoon or Modular based EPS can be used as a construction structure which floating in the water. Due to the material base of EPS material, then the material will not be damaged due to fresh water, sea water, chemicals, oil, gas, and ultraviolet. 
The load capacity per module meter is 5 tons per $\mathrm{kg}$. The Pontoon technology is the result of fabrication that can be applied for various structural and architectural purposes both on land and on water. The advantages are environmentally friendly and the dimensions of structural materials can be custom this material has a heat resistance of up to 600. The picture below is an example of an EPS module that has been applied as a floating structure.

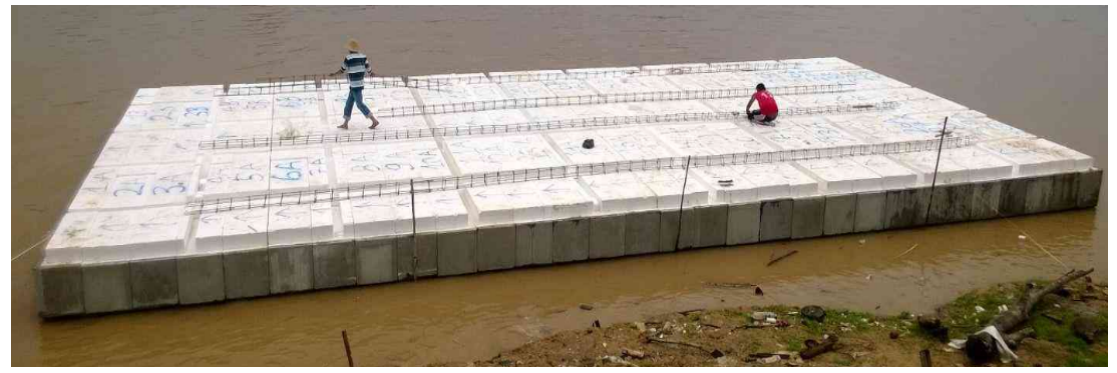

Fig. 8. Pontoon Modular EPS

Source: B-Foam, 2017

Table 1. Characteristic and Specification of Pontoon EPS

\begin{tabular}{|c|c|}
\hline \multicolumn{2}{|c|}{ Material Characteristic of EPS } \\
\hline Floating Carrying Capacity & $>950 \mathrm{~kg} / \mathrm{m} 3$ gross volume of EPS submerged in the water \\
\hline Water Infiltration Level & $\begin{array}{l}<1 \%(\text { vol } / \text { vol }) \text { after } 30 \text { months } \\
<5 \% \text { after } 15 \text { years underground }\end{array}$ \\
\hline Service Period (Durability) & Very Long ( $>50$ years) \\
\hline Dimensional stability & $+/-<2 \%($ ASTM Test Method D2126) \\
\hline $\begin{array}{l}\text { Environmental compatibility } \\
\text { \& chemical stability }\end{array}$ & $\begin{array}{l}\text { Does not contain harmful pollutant-cadmium, mercury, lead, } \\
\text { hexavalent inert chromium - does not release chemicals (non- } \\
\text { leaching) }\end{array}$ \\
\hline $\begin{array}{l}\text { Condition damage the } \\
\text { material }\end{array}$ & $\begin{array}{l}\text { - Direct UV light } \\
\text { - Insects } \\
\text { - Various types of liquid hydrocarbons (solvent, gasoline) }\end{array}$ \\
\hline Advantages & $\begin{array}{l}\text { - Non-porous and non-decaying, and Durable (Life span } 30 \\
\text { years and it will be } 3 \text { times when given a polyethylene } \\
\text { coating thickness of } 3 \mathrm{~cm} \text { ) } \\
\text { - } \quad \text { Flexible in terms of various dimensions (custom) } \\
\text { - } \quad \text { Easy in construction } \\
\text { - Minimum maintenance } \\
\text { - High buoyancy } \\
\text { Eco-friendly production with recycled blend does not use } \\
\text { CFCs }\end{array}$ \\
\hline \multicolumn{2}{|l|}{ Technical Specification } \\
\hline Material & Expanded Polystyrene \\
\hline Density & $12 \mathrm{Kg} / \mathrm{m}^{3}$, or custom order \\
\hline Maximum Load & 5 Ton $/ \mathrm{m}^{2}$ \\
\hline Module Size & $\begin{array}{l}\text { Maximum } 600 \text { x } 100 \text { x } 60 \mathrm{~cm} \text { (floating capacity max: } 3 \\
\text { ton/module) }\end{array}$ \\
\hline Grant-series potoon & $\begin{array}{l}\text { - Casing : Flexible polymer - cementations matrix filer on lock- } \\
\text { stitch knitted, UV-resistant and Oxidation-free Polyethylene } \\
\text { mesh. } \\
\text { - Positive-Lock grooves adhesion with concrete casting top }\end{array}$ \\
\hline
\end{tabular}




\begin{tabular}{|l|l|}
\hline Price assumption & $\begin{array}{l}\text { Rp 2.500.000,- + Inflation } \\
\text { (because fabrication is customary thus the material is flexible } \\
\text { in serving the needs of EPS pontoon dimension based on } \\
\text { construction load and life or dead span of the building, this } \\
\text { price is based on prior research that has thickness dimension } 1 \\
\mathrm{~m} \text { ) }\end{array}$ \\
\hline
\end{tabular}

Source: Compilation of EPS Pontoon website data and 2016 Tambak Lorok Floating Center's research data.

\subsection{Engineering of Lanting house design with EPS}

\subsubsection{Banjarmasin Floating Residential (Lanting house)}

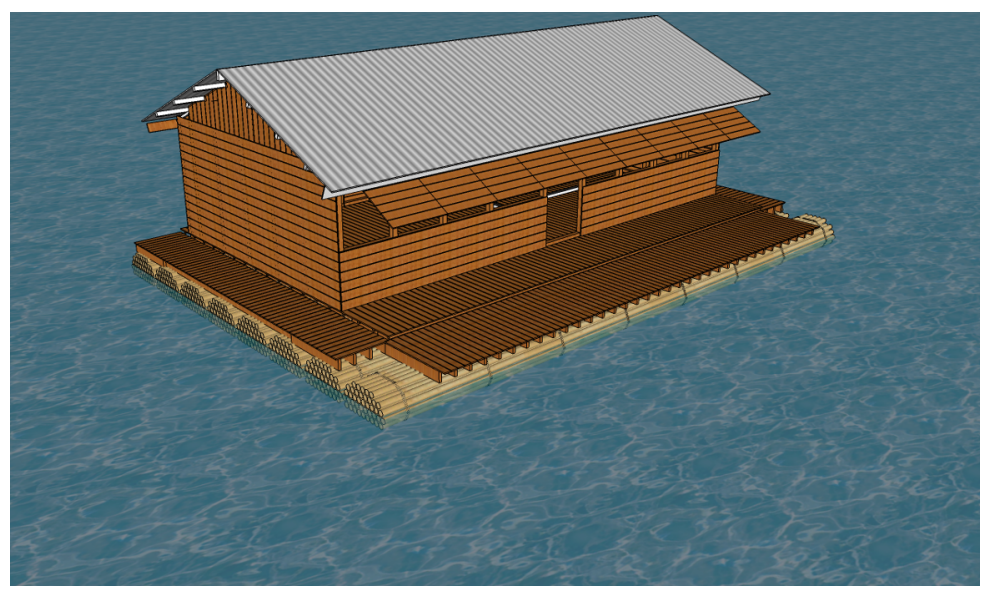

Fig. 9. Lanting house, Banjarmasin Traditional Floating House

Source: Interim report Housing Technology Applied R\&D Center Report PUPR,2017

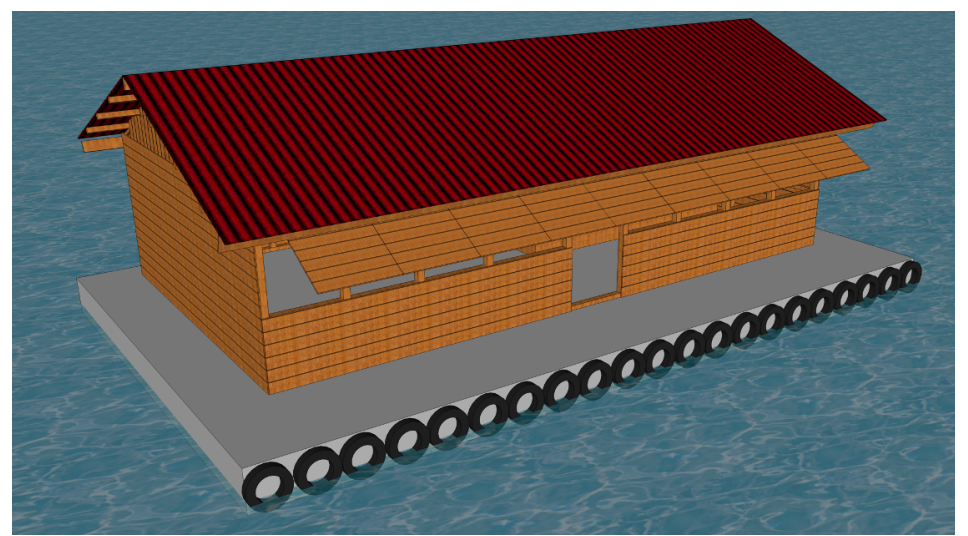

Fig. 10. Pontoon EPS Structured Lanting house

Source: Interim report Housing Technology Applied R\&D Center Report PUPR,2017

In figure 9 floating house/Lanting house in Muara Mantuil, Banjarmasing is inhabited by one family comprising of 3 family members, the livelihood of the head of the family is grocery store merchant serving Seberang Barito river and Muara Mantuil community. It affects the needs of space on the terrace to facilite the buyer accessing the grocery store, the 
terrace dimension used as the access of the buyer has dimension $1.5 \mathrm{~m}$ and $1.25 \mathrm{~m}$ enough for 2 people crossing path and 2 people standing transacting in front of the store. Unlike the Lanting house whose function as a residential it does not have terrace dimension as wide as grocery store. Therefore the floating housing needs of Martapura riverbank has variation based on the occupation of the head of the family. The placing of space function is the most critical factor in considering the stability and equilibrium of the house.

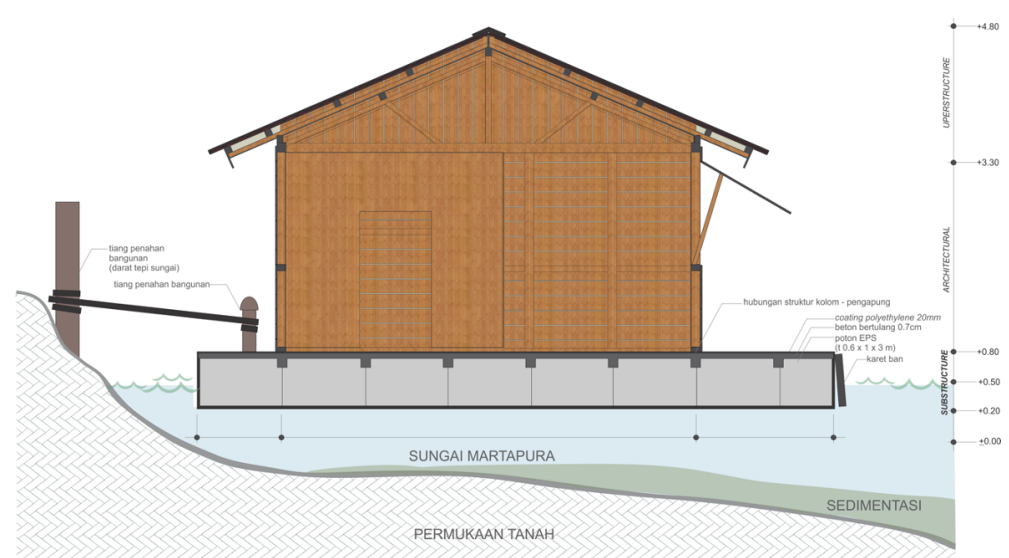

Fig. 11. Figure of Illustration of Local floating house structure with EPS Potoon combination Source: Final report Housing Technology Applied R\&D Center Report PUPR,2017

Figure 11 illustrates of Banjarmasin local floating building which structured EPS potoon. EPS potoon material is very flexible in terms of material structure integration with one another. In the implementation of EPS potoon material as float structure could assist the government in reducing slums of riverbank. The foundation of floating house consisted of small dimension material arrangements which quite complex causes the rubbish easily caught in the vicinity of the riverbank and makes it difficult in the handling and cleaning process since it tucked in bamboo. As well as stilt house issue which has many poles in Martapura riverbank.

The structure of floating house which using EPS potoon is illustrated in above figure. The arrangement of the structure is simpler and the building seems cleaner. The front of the floating part is completed with rubber tires to respond direct clash with the boats that will pull over by the house. In above figure described that for house size equal to Lanting house building dimension, figure 11 is the field survey result. With the function of the building is residential and grocery store with dimension $6 \times 9 \mathrm{~m}$. Therefore the EPS potoon that can be used is with module $0,6 \times 1 \times 3 \mathrm{~m}$ that has load capacity $200 \mathrm{~kg} / \mathrm{m} 2$. Floor plate of concrete reinforced cast is coated with coating polyethylen with $2 \mathrm{~cm}$ thickness. The coating is responding the possibility if there are spoiled hydrocarbon and hit the building float. The building retaining pole is simply put in the mainland or bank river, this position reponds the Banjarmasin government policy prohibiting to place the building retaining pole in Martapura river body.

The architectural and upperstructurural parts are still illustrated with woor frame that resembles existing Lanting house. However the structure and architecture element will be replaced with other material beside wood, adjusting with the user's needs. It is adviced to have a light material. At the floating building located in riverbank it is best to have a good sewage management system and completed with biofil puskim technology, hence the waste is not disposed to the river. For electric power uses solar panels to reduce short risk of State 
Electicity Company's cable and it is more environmentally friendly and independent electricity source.

\subsubsection{Comparison of characteristic of local float material and EPS pontoon}

Table 2. Comparison of Characteristic of EPS Pontoon Technology with local techology of Lanting house based on Technology Characteristic variable

\begin{tabular}{|c|c|c|c|}
\hline No & $\begin{array}{c}\text { Characteristic of } \\
\text { Technology }\end{array}$ & Potoon EPS & House Local Technology \\
\hline 1 & $\begin{array}{l}\text { Structural } \\
\text { security }\end{array}$ & $\begin{array}{l}200 \mathrm{~kg} / \mathrm{m}^{2} \mathrm{~s} / \mathrm{d} 5 \mathrm{Ton} / \mathrm{m}^{2} \text { adjusting } \\
\text { to the needs of building structure } \\
\text { load }\end{array}$ & $200 \mathrm{~kg} / \mathrm{m}^{2}$ every 800 bamboo \\
\hline 2 & $\begin{array}{l}\text { Resistance and } \\
\text { security to the } \\
\text { structure }\end{array}$ & $\begin{array}{l}\text { - High buoyancy }>950 \mathrm{~kg} \mathrm{/} \mathrm{m3} \\
\text { gross volume of EPS submerged } \\
\text { in water } \\
\text { - EPS potoon float material uses } \\
\text { coating polyethylene or cast } \\
\text { concrete that is not easily } \\
\text { conducting fire. }\end{array}$ & $\begin{array}{l}\text { - High buoyancy is good, it is } \\
\text { not counted in numbers } \\
\text { - Bamboo float material does } \\
\text { not have any coating layers } \\
\text { and has a wooden floor that } \\
\text { easily deliver the fire }\end{array}$ \\
\hline 3 & $\begin{array}{l}\text { Ease of } \\
\text { Implementation }\end{array}$ & Easier and simpler in construction & $\begin{array}{l}\text { Has float structure element } \\
\text { that is not simple }\end{array}$ \\
\hline 4 & $\begin{array}{l}\text { Structural } \\
\text { durability }\end{array}$ & Structural durability $>50$ years & $\begin{array}{l}\text { Bamboo durability } 2-5 \text { years } \\
\text { needs to replace weathered } \\
\text { bamboo. }\end{array}$ \\
\hline 5 & Dimension scale & $\begin{array}{l}\text { Flexible according to the needs } \\
\text { (custom dimension) }\end{array}$ & $\begin{array}{l}\text { Dimension needs to consider } \\
\text { the bamboo dimension } \\
\text { available in Banjarmasin }\end{array}$ \\
\hline 6 & $\begin{array}{l}\text { Material } \\
\text { availability }\end{array}$ & $\begin{array}{l}\text { Factory in Batujajar at present, } \\
\text { Bandung, Indonesia }\end{array}$ & Local material of Banjarmasin \\
\hline 7 & $\begin{array}{l}\text { Function } \\
\text { integration }\end{array}$ & Very possible and flexible & Less flexible \\
\hline 8 & $\begin{array}{l}\text { Structural } \\
\text { strength }\end{array}$ & $\begin{array}{l}\text { EPS pontoon response to wind and } \\
\text { river water waves is good and very } \\
\text { stable. }\end{array}$ & $\begin{array}{l}\text { The response of float bamboo } \\
\text { to wind and water waves is } \\
\text { less stable }\end{array}$ \\
\hline 9 & $\begin{array}{l}\text { Economic and } \\
\text { Budget }\end{array}$ & Not yet counted & $\begin{array}{l} \pm \text { Rp } 32.000 .000,- \text { new float } \\
\text { construction has building } \\
\text { dimension } 5 \text { x } 9 \text { m without } \\
\text { architectural part and building } \\
\text { roof. Daily maintenance cost } \\
\text { every } 2-5 \text { years is excluded. }\end{array}$ \\
\hline 10 & $\begin{array}{l}\text { Structural } \\
\text { visualization }\end{array}$ & $\begin{array}{l}\text { Good visualization, look cleaner } \\
\text { since there are coating finishing of } \\
\text { EPS potoon }\end{array}$ & $\begin{array}{l}\text { The visualization is not neat } \\
\text { and there is no coating } \\
\text { finishing }\end{array}$ \\
\hline
\end{tabular}

Source: Housing Technology Applied R\&D Center Report PUPR,2017

Based on comparison result of above table that EPS potoon technology has advantages in the structural security, structural durability, durability, ease of implementation, dimension scale, structural integration, and structural visual. This will assist the community/regional government in preserving local wisdom which is a water culture in Banjarmasin and Palembang city.

It is more notably to the arrangement of riverbank residential and the arrangement of water tourism zone in Palembang and Banjarmasin city. It may be saving maintenance cost 
of floating building at its floating structure and saving time in the float construction. Due to the EPS potoon construction is not as complex as the structure of local float made of bamboo. At economic and budget variable nowadays can not be emerged for it needs particular calculation process that will be completed soon.

\subsubsection{Conformity of EPS Pontoon Material Technology as Float Material Alternative in Martapura river}

Table 3. Comparison of EPS Pontoon Technology Characteristic with Local Technology of Lanting house Based on Character Variable of Martapura river, Banjarmasin

\begin{tabular}{|c|c|c|c|}
\hline No. & $\begin{array}{l}\text { Characteristic of } \\
\text { Martapura river }\end{array}$ & EPS Pontoon & Bamboo Float \\
\hline 1 & River ebb $<50 \mathrm{~cm}$ & $\begin{array}{l}\text { EPS pontoon can be used on the } \\
\text { difference of water with the } \\
\text { Pontoon material by } 20 \mathrm{~cm}\end{array}$ & $\begin{array}{l}\text { At present this material is } \\
\text { still used and it does not } \\
\text { constrained. }\end{array}$ \\
\hline 2 & $\begin{array}{l}\text { Water content } \\
\text { (chemical/liquid } \\
\text { hydrocabons) }\end{array}$ & $\begin{array}{l}\text { EPS material itself can not } \\
\text { intersect with liquid } \\
\text { hydrocarbon, but EPS pontoon } \\
\text { has technology of finishing } \\
\text { coating polyethylene thickness } 3 \\
\text { cm that can hold the substances } \\
\text { absorbed by EPS Pontoon. } \\
\text { Hence the EPS pontoon can be } \\
\text { used in Martapura river. }\end{array}$ & $\begin{array}{l}\text { It does not constraint with } \\
\text { chemical waste. }\end{array}$ \\
\hline 4 & $\begin{array}{l}\text { River as a boat } \\
\text { transportation route. } \\
\text { (clash of boat) }\end{array}$ & $\begin{array}{l}\text { Using conventional solution, at } \\
\text { the foundation float is coated } \\
\text { with used tires. }\end{array}$ & $\begin{array}{l}\text { Use conventional solution, } \\
\text { at the foundation float part } \\
\text { is coated with used tires. }\end{array}$ \\
\hline 5 & $\begin{array}{l}\text { Martapura river has } \\
\text { regular maintenance } \\
\text { schedule for the river } \\
\text { dredging of } \\
\text { Martapura river. }\end{array}$ & $\begin{array}{l}\text { The float building system uses } \\
\text { EPS pontoon float material that } \\
\text { is flexible and can be moved } \\
\text { around as needed. }\end{array}$ & $\begin{array}{l}\text { Float building system uses } \\
\text { bamboo float material that } \\
\text { is flexible and can be } \\
\text { moved around as needed. }\end{array}$ \\
\hline 6 & $\begin{array}{l}\text { The needs of Float } \\
\text { Building } \\
\text { Construction }\end{array}$ & $\begin{array}{l}\text { 1. Black water and grey water } \\
\text { solution uses biofill puskim. } \\
\text { 2. Electricity energy solution } \\
\text { uses solar panel. }\end{array}$ & $\begin{array}{l}\text { Has not accommodate the } \\
\text { black water, electrical } \\
\text { energy and clean water. }\end{array}$ \\
\hline 7 & $\begin{array}{l}\text { Material impact on } \\
\text { environment }\end{array}$ & $\begin{array}{l}\text { 1. EPS Potoon is produced from } \\
\text { Styrofoam waste in Bandung. } \\
\text { 2. Waste can be recycled by } \\
\text { fabrication }\end{array}$ & $\begin{array}{ll}\text { 1. } & \text { Local bamboo } \\
\text { 2. } & \text { Bamboo waste can } \\
\text { decompose by itself. }\end{array}$ \\
\hline
\end{tabular}

Source: Final report Housing Technology Applied R\&D Center Report PUPR,2017

At table 3, indicates that the comparison of characteristic of EPS Pontoon technology and local bamboo float technology in Banjarmasin (Lanting house) is based on Martapura river characteristics. EPS pontoon has deeper value in responding river tides, river waste, boat collision, right movement and infrastructure solution. However in relation to the environment the EPS pontoon needs a fabrication process in term of unused waste handling, while the bamboo can be processed due to naturally decomposed. 


\section{Conclusions}

The conclusions of this study are:

a. For the typology of Lanting house in Banjarmasin, the construction of Lanting house roof generally uses saddle shape, a light and simple roof construction. All Lanting houses in Martapura river uses saddle roof construction. Material used in the building depends on the economic level of the residents. Of the percentage of the roof shape and material in Martapura river, all roof shape is saddle and the building material is mostly in the form of zinc, Sago palm and shingle board. Other percentage of its building materials are Sago palm and shingle.

b. The load capacity EPS per module meter is 5 tons per $\mathrm{kg}$. This Pontoon technology is the result of fabrication that can be applied for various structural and architectural purposes both on land and on water. Having advantages other than environmentally friendly and the dimensions of structural materials can be custom this material has a heat resistance of up to 600 .

c. Float house structure which uses EPS pontoon is illustrated in this study The structure arrangement is simpler and the building looks neater. The front of float part is completed with rubber tires to respond direct clash of boats that will be pulling over to the building. It also described that for the size of the house is equal to the Lanting house dimension. With the building function namely residential and grocery stores (example) with dimension $6 \times 9 \mathrm{~m}$. therefore the EPS pontoon that can be used is module $0,6 \times 1 \times 3 \mathrm{~m}$ with load capacity by $200 \mathrm{~kg} / \mathrm{m} 2$. Floor plate of reinforced concrete cast is coated with coating polyethylen with thickness $2 \mathrm{~cm}$. This coating responds on the possibility of spoiled hydrocabon and hit the building float.

d. From Comparison of characteristic of local float material and EPS pontoon, EPS pontoon is reliable and better than float material. If EPS pontoon will be implemented in Martapura river Banjarmasin, it better than bamboo float.

\section{Acknowledgment}

This paper is a part of research publication on the appropriate floating technology for building funded by Research and Development Centre on Policy and Application of Technology, Ministry of Public Work and Housing Settlement. Also, some of data using document research grant of International Research Collaboration and Scientific Publication, Ministry of Research, Technology and Higher Education, Indonesia (663/M/KP/XII/2015 and 041/HB-LT/IV/2017). All figures designed by Harum I. Mahadma.

\section{References}

1. B-Foam Technology, Beton Elemindo Putra, Bandung, (2017) (unpublished)

2. BPS Kota Banjarmasin, Banjarmasin dalam Angka, (2017)

3. Balitbang PTP Yogyakarta, (Housing Technology R and D Center), Final Report Penyiapan Penerapan Teknologi Struktur Bangunan Rumah (Hunian Apung), (2017) (unpublished)

4. Balitbang PTP Yogyakarta (Housing Technology R and D Center), Interim Report Penyiapan Penerapan Teknologi Struktur Bangunan Rumah (Hunian Apung), (2017) (unpublished) 
5. Daryanto, Bambang., Rumah Lanting: Rumah Diatas Air Tinjauan Aspek Tipologi Bangunan, Jurnal Kelimuan dan Aplikasi Teknik, https://ppjp.ulm.ac.id/journal/index.php/infoteknik/article/view/1663, , (2016) accessed October $2^{\text {nd }}, 2018$.

6. Rahman, 2014. Pelestarian Rumah Lanting Berlandaskan Budaya Sungai Masyarakat Kota Banjarmasin, E-Journal Graduate Unpar Vol. 1, No. 2, (2014), http://journal.unpar.ac.id/index.php/unpargraduate/article/view/1054 accessed October $7^{\text {th }} 2018$. 